\title{
Care Model and Effectiveness of Dementia Special Care Units- a Cross-sectional Survey in China
}

\author{
Xiaoxin Dong \\ Ningbo College of Health Sciences \\ Tongda Sun \\ Ningbo College of Health Sciences \\ Rangcheng Jia ( $\nabla 26288874 @ q q . c o m$ ) \\ Ningbo College of Health Sciences \\ Lingbo Zhao \\ Ningbo College of Health Sciences \\ Ning Sun \\ Ningbo College of Health Sciences
}

\section{Research article}

Keywords: Dementia, Dementia special care unit, Care model, Effectiveness

Posted Date: April 5th, 2021

DOI: https://doi.org/10.21203/rs.3.rs-384438/v1

License: (c) (i) This work is licensed under a Creative Commons Attribution 4.0 International License. Read Full License 


\section{Abstract}

Background: Dementia special care unit (D-SCU) is a main care mode for the elderly with dementia, and has increased steadily internationally. However, little is known about the D-SCUs of China. The present study aimed to analyze and summarize the types and standards of D-SCUs in China, and evaluate the care efficiency of the D-SCU care model.

Methods: A cross-sectional survey was conducted between June 2018 and July 2019 in 6 cities of China. Quantitative data about the basic information and the care satisfaction were collected from 25 care facilities in the 6 cities. Qualitative data about the care status of the elderly with dementia, the standards, the management and the operation of the D-SCUs were collected among the 25 care facilities and the 3 cities that had issued standards for setting D-SCUs. Grounded theory method was used to analyze the qualitative data, and data envelopment analysis (DEA) method was applied to evaluate the care efficiency of the D-SCU care model.

Results: The technical efficiency, pure technical efficiency and scale efficiency of care facilities with D-SCUs were higher than those of care facilities without D-SCUs ( $P=0.016, P=0.022$, and $P=0.021$, respectively). The types of D-SCUs could be divided into independent, semiindependent, semi-dependent and dependent according to the architecture, physical space, and management mode. The standards for the area, environment, beds, service items of the D-SCUs were various among the 3 cities that had issued standards for setting D-SCUs.

Conclusions: The care model of D-SCUs is effective and professional, and can be further promoted in China. The exploration and standard research on the D-SCUs should be strengthened in future.

\section{Background}

Dementia is a chronic or progressive central nervous system degenerative syndrome, manifested as a series of cognitive impairment, emotional control and social behavior problems, and is known as an epidemic disease in the world currently. Dementia has been listed as the fourth most common cause of death after heart disease, cancer and stroke[1]. Around the world, there will be one new case of dementia every 3 seconds. 50 million people worldwide are living with dementia 2019, and the number will more than triple to 152 million by 2050 . The total estimated cost of dementia reaches USD 1 trillion and is expected to reach USD 2 trillion by 2030[2].

China has become an aging society in the past 20 years, and dementia is increasing rapidly in China. It was estimated that there were 12 million elderly with dementia in China in 2019 , accounting for about $5 \%$ of the elderly population[3], ranking first in the world, accounting for $40 \%$ of the total number of elderly people with dementia in the Asia-Pacific region and about $20 \%$ of the total number of elderly people with dementia in the world[4]. Due to the particularity of dementia, care difficulty and pressure for the elderly with dementia are larger than those for the general elderly. At present, the care mode of the elderly with dementia in China is still dominated by home care, but this model not only causes serious care pressure for families, but also lacks professionalism[5-7]. As a result, the life quality of the elderly with dementia and their family caregivers is generally low. Care for the elderly with dementia has created serious challenges to social development, social security and long-term care systems.

Institutional care is one of the main ways for the elderly with dementia to obtain professional care[8]. The living styles of the elderly with dementia in these care facilities include isolation (not living with other elderly) and mixed (living with other elderly). Dementia special care unit (D-SCU), which is especially designed through structural design, staffing and activity plans, aims to provide supportive social and physical environments for the elderly with dementia, is the main mode for realizing isolated living. In the past decade, the number of D-SCU has increased steadily internationally $[9,10]$. However, in China, the long-term care systems for elderly with dementia have not yet been established[6]. The resources, such as care facilities, equipment and caregivers are very limited, especially professionals for dementia. Only a small number of care facilities are willing or able to accept the elderly with dementia, and even fewer institutions have set up D-SCUs for them. At present, the guiding document for the establishment of D-SCU has not yet been implemented at the national level, and only in recent years, certain cities begin to explore the care ways of D-SCUs at the city level. Then what is the model of D-SCUs in China? Is this model effective? and whether it is suitable for promotion in China? Little is known about these.

This study addressed this knowledge gap by use of cross-sectional survey to grasp the care model and the effectiveness of the D-SCUs in China. In the study, we analyzed and summarized the types and standards of the D-SCUs in China, and compared the care efficiencies of the elderly with dementia between care facilities with and without D-SCUs using data envelopment analysis (DEA) method. The study could provide scientific reference for policy making and industry development.

\section{Methods}

\section{Study sample and data collection}


Questionnaire Survey. A cross-sectional study was carried out between June 2018 and July 2019 in 4 eastern cities (Shanghai, Qingdao, Ningbo and Changzhou), 1 central city (Zhengzhou), and 1western city (Chengdu) of China. Objective Sampling and convenience sampling were performed, and 25 care facilities that accepting the elderly with dementia were selected from the 6 cities. Questionnaire survey was conducted among these 25 care facilities. The questionnaire was developed (Additional file 1) and consisted of the basic information of the care facility, the human resources allocation, the setting of the D-SCUs, and the satisfaction of the elderly with dementia. The satisfaction involves 6 items: living environment, recreational and fitness equipment, dietary conditions, attitude of nursing staff, knowledge and skills of nursing staff, service items. Satisfaction of each item divided into five levels ( 5 points for very satisfying, 4 points for satisfying, 3 points for neutral, 2 points for dissatisfying, 1 point for very dissatisfying). The contents of the basic information of the care facility, the human resources allocation and the setting of the D-SCUs were filled in by the facility managers. Given the mental state of the elderly with dementia, the items of satisfaction were filled in by their relative who came to see them frequently. Finally, the satisfaction scores of 1046 elderly people with dementia were effectively collected.

Semi-structured in-depth interviews. "Interview Outline for Facility Manager" (Additional file 2) and "Interview Outline for Civil Affair or Medical Insurance Department Manager" (Additional file 3) were developed based on literature review and expert consultation. " "Interview Outline for Facility Manager" was applied to interview the managers of the 25 facilities surveyed, and the contents involved the management mode, operation status, and care status of the elderly with dementia. 区Three cities (Shanghai, Qingdao, and Chengdu) out of the 6 selected cities have formulated standards for D-SCUs setting at the city level. "Interview Outline for Civil Affair or Medical Insurance Department Manager "was applied to interview the Manager of Civil Affair or Medical Insurance Department of these 3 cities, and the contents involved the setting standards, management, service models of the D-SCUs. Each interview lasted 20 to 40 minutes, and two researchers participated simultaneously, one in charge of the interview and the other in charge of recording.

\section{Analysis}

Qualitative analysis. All of the interview data were analyzed by the first author (Xiaoxin Dong) using grounded theory approach[11]. The analysis was done manually. In the first step, close reading of the interview records was done to familiarize and identify the key themes emerging from the interviews. In the second step, a line-by-line coding of the interview records was performed using a three-stage coding process involving open coding, axial coding and selective coding, in order to identify and name concepts and categories and to determine their relationships[12]. The coding and categorization were done by using the Microsoft Office Word.

Quantitative analysis. In quantitative analysis, we followed a two-stage process. First, we took each care facility surveyed as a decisionmaking unit (DMU), and the efficiency value of each DMU was calculated using DEA method. Second, the care efficiencies were compared by statistical significance tests between care facilities with and without D-SCUs. A similar approach was employed in previous studies, such as Ozcan et al.[13] and Björkgren et al.[14]. Means and Medians were used to indicate the central tendency of the basic information of inputs and outputs and the efficiency values. In view of a normal distribution of efficiency scores cannot be assumed in DEA model[13], the differences between the two groups were tested by the nonparametric Wilcox test of median efficiency levels. Deep2.1 software and SPSS25.0 were applied for DEA analysis and statistical significance tests, respectively, with a significance level of a=0.05.

\section{DEA Model}

DEA is a quantitative analysis method that uses linear programming to evaluate the relative effectiveness of comparable DMU based on multiple inputs and multiple outputs.DEA does not require specification of functional form[14], can also handle efficiency evaluation under the conditions of multiple inputs and multiple outputs, which has become a common analysis tool for enterprise resource allocation[13-16]. Since DEA is a cutting-edge analysis technology that uses linear programming to identify production frontiers and is completely driven by data, using DEA to analyze the efficiency of care facilities can avoid the problem of subjectively assigning index weights, minimize arbitrariness, and improve the scientificity of decision-making and the objectivity of evaluation.

The DEA method mainly includes $C^{2} R$ model and $B^{2} C$ model. $C^{2} R$ model is mainly used to evaluate the relative effectiveness of the DMU to determine whether the technology and the scale are effective at the same time. The final comprehensive efficiency value or technical efficiency (TE) is $\theta$, which can be effected by resource utilization and resource allocation. When $\theta=1$, the DMUj technology is valid, indicating that the management model and scale efficiency have reached the best level under the current inputs and outputs. when $0<\theta<1$, the $\mathrm{DMUj}$ technology is invalid. The larger the $\theta$ value, the higher the efficiency of the DMUj relative to other DMUs. $\mathrm{BC}^{2}$ model decomposes the TE of DMU into pure technical efficiency (PTE) and scale efficiency (SE). PTE refers to production efficiency that affected by management technology and production technology, and SE generally refers to whether a DMU is operating with optimal production size for producing a defined output. TE= PTEXSE.

\section{Inputs and outputs}


In previous DEA studies of nursing homes, researchers tended to choose the number of different types of nursing home staff[15, 17-19], bed number[14, 17, 20], value of fixed assets[14] as input variables, and the resident number[17], the satisfaction of residents[16], the days the resident stay[14, 20,21], and income[16] as output variables. Based on these studies and the common assumption of labor and capital as the basic inputs for a production function [14], in this DEA models, we used building area, number of open beds and nursing staff as the inputs. The building area and number of open beds was included as proxies for capital, and the number of nursing staff was included as proxy for labor. In terms of outputs, we think that service quality can directly affect the service effects and the development of facilities. Therefore, outputs can be selected from the perspective of residents, and then we choose the number and the care satisfaction of the elderly resident with dementia as outputs in this model.

\section{Results}

\section{Styles and characteristics of D-SCUs}

According to on-site investigations and interviews, the styles of D-SCUs in China can be divided into four categories: independent, semiindependent, semi-dependent and dependent based on the relative independence of architecture, the physical space, and the management mode. The building space of independent and semi-independent D-SCUs was set up separately, while the building space of semi-dependent and dependent D-SCUs was shared with other elderly residents. In addition, there were some differences in terms of architectural space, living space, public activity space, management personnel and service personnel among the four types of D-SCUs, as shown in Table 1.

Table 1

Types and Characteristics of D-SCUs in China

\begin{tabular}{|c|c|c|c|c|c|}
\hline Style & Architectural space & Living space & Public activity space & Manager & Care personnel \\
\hline Independent & $\begin{array}{l}\text { Completely independent: } \\
\text { independent care facilities } \\
\text { specially set up for the } \\
\text { elderly with dementia }\end{array}$ & $\begin{array}{l}\text { Completely } \\
\text { independent: there } \\
\text { were only the elderly } \\
\text { with dementia, none } \\
\text { other elderly }\end{array}$ & $\begin{array}{l}\text { Completely } \\
\text { independent: there } \\
\text { were only the elderly } \\
\text { with dementia, none } \\
\text { other elderly }\end{array}$ & $\begin{array}{l}\text { Completely } \\
\text { independent: } \\
\text { dedicated } \\
\text { managers }\end{array}$ & $\begin{array}{l}\text { Completely } \\
\text { independent: dedicated } \\
\text { care personnel }\end{array}$ \\
\hline $\begin{array}{l}\text { Semi- } \\
\text { independent }\end{array}$ & $\begin{array}{l}\text { Independent: an } \\
\text { independent building } \\
\text { divided for the elderly with } \\
\text { dementia in care facilities } \\
\text { generally }\end{array}$ & $\begin{array}{l}\text { Independent: there } \\
\text { were only the elderly } \\
\text { with dementia, none } \\
\text { other elderly }\end{array}$ & $\begin{array}{l}\text { Independent: there } \\
\text { were only the elderly } \\
\text { with dementia, none } \\
\text { other elderly }\end{array}$ & $\begin{array}{l}\text { Shared: co- } \\
\text { operate with } \\
\text { other parts } \\
\text { of the care } \\
\text { facilities }\end{array}$ & $\begin{array}{l}\text { Independent: dedicated } \\
\text { care personnel }\end{array}$ \\
\hline $\begin{array}{l}\text { Semi- } \\
\text { dependent }\end{array}$ & $\begin{array}{l}\text { Dependent: a closed } \\
\text { region or floor isolated } \\
\text { from other elderly in the } \\
\text { same building }\end{array}$ & $\begin{array}{l}\text { Independent: there } \\
\text { were only the elderly } \\
\text { with dementia, none } \\
\text { other elderly }\end{array}$ & $\begin{array}{l}\text { Independent: there } \\
\text { were only the elderly } \\
\text { with dementia, none } \\
\text { other elderly }\end{array}$ & $\begin{array}{l}\text { Shared: co- } \\
\text { operate with } \\
\text { other parts } \\
\text { of the care } \\
\text { facilities }\end{array}$ & $\begin{array}{l}\text { Independent: dedicated } \\
\text { care personnel }\end{array}$ \\
\hline Dependent & $\begin{array}{l}\text { Dependent: a semi- } \\
\text { enclosed region or floor } \\
\text { isolated from other elderly } \\
\text { in the same building }\end{array}$ & $\begin{array}{l}\text { Independent there } \\
\text { were only the elderly } \\
\text { with dementia, none } \\
\text { other elderly }\end{array}$ & $\begin{array}{l}\text { Shared: sharing } \\
\text { activity space with } \\
\text { other elderly }\end{array}$ & $\begin{array}{l}\text { Shared: co- } \\
\text { operate with } \\
\text { other parts } \\
\text { of the care } \\
\text { facilities }\end{array}$ & $\begin{array}{l}\text { Independent or shared: } \\
\text { dedicated care } \\
\text { personnel or sharing } \\
\text { care personnel with } \\
\text { other elderly }\end{array}$ \\
\hline
\end{tabular}

\section{Standards of D-SCUs}

The standards for setting up D-SCUs in Chengdu, Qingdao and Shanghai were mainly considered from facility style, area, environment, beds, personnel, and service items. All the three cities stipulated that the aged care facilities could set up D-SCUs. Qingdao and Chengdu also stipulated that medical service facilities could also set up D-SCUs. All cities had regulations on environmental standards, care personnel standards and service items for D-SCUs, but the relevant regulations were very different and not very detailed. There were also some other different regulations on area standard, bed standard and manager standard for D-SCUs as shown in Table 2. Shanghai advocated homestyle care, and there were clear regulations on the number of beds and caregivers for each D-SCU, and the service items involved physical, psychological, and social dimensions. 
Table 2

Standards of D-SCUs in Qingdao, Chengdu and Shanghai of China

\begin{tabular}{|c|c|c|c|c|c|c|c|}
\hline City & $\begin{array}{l}\text { Facility style that could } \\
\text { open a D-SCU }\end{array}$ & $\begin{array}{l}\text { Area } \\
\text { standard }\end{array}$ & $\begin{array}{l}\text { Environment } \\
\text { standard }\end{array}$ & Bed standard & $\begin{array}{l}\text { Manager } \\
\text { standard }\end{array}$ & $\begin{array}{l}\text { Care } \\
\text { personnel } \\
\text { standard }\end{array}$ & $\begin{array}{l}\text { Service } \\
\text { items }\end{array}$ \\
\hline Qingdao & $\begin{array}{l}\text { (1)Nursing care facilities } \\
\text { (2)Medical service } \\
\text { facilities } \\
\text { (3)Aged care facilities }\end{array}$ & $\begin{array}{l}\text { Not } \\
\text { specified }\end{array}$ & $\begin{array}{l}\text { Enclosed } \\
\text { management }\end{array}$ & $\begin{array}{l}\text { (1)At least } 20 \\
\text { beds should } \\
\text { be provided in } \\
\text { institutions } \\
\text { undertaking } \\
\text { long-term care } \\
\text { services. } \\
\text { (2)At least } 8 \\
\text { beds should } \\
\text { be provided in } \\
\text { the care } \\
\text { service chain. } \\
\text { (3)Institutions } \\
\text { that } \\
\text { undertaking } \\
\text { day care and } \\
\text { short-term } \\
\text { care services, } \\
\text { should set up } \\
\text { a } \\
\text { corresponding } \\
\text { number of } \\
\text { beds } \\
\text { according to } \\
\text { the scale of } \\
\text { service. }\end{array}$ & Not specified & $\begin{array}{l}\text { At least } 2 \\
\text { medical staff, } \\
\text { social } \\
\text { workers or } \\
\text { senior nursing } \\
\text { staff who } \\
\text { have been } \\
\text { trained in } \\
\text { dementia care } \\
\text { should be } \\
\text { provided. }\end{array}$ & $\begin{array}{l}\text { (1)Medical } \\
\text { care } \\
\text { (2)Life care }\end{array}$ \\
\hline Chengdu & $\begin{array}{l}\text { (1)Medical service } \\
\text { facilities } \\
\text { (2)Aged care facilities } \\
\text { (3)Care facilities that } \\
\text { provide home care } \\
\text { services for the elderly }\end{array}$ & $\begin{array}{l}\text { Not } \\
\text { specified }\end{array}$ & $\begin{array}{l}\text { Quiet, safe, } \\
\text { and } \\
\text { comfortable } \\
\text { first floor or } \\
\text { the floors } \\
\text { with elevator. } \\
\text { Besides, } \\
\text { independent } \\
\text { and safe } \\
\text { outdoor } \\
\text { activity area } \\
\text { is required. }\end{array}$ & Not specified & $\begin{array}{l}1 \text { full-time } \\
\text { manager }\end{array}$ & $\begin{array}{l}1 \text { registered } \\
\text { doctor and } 1 \\
\text { registered } \\
\text { nurse is } \\
\text { required, or an } \\
\text { agreed } \\
\text { medical } \\
\text { institution } \\
\text { can provide } \\
\text { timely } \\
\text { medical care } \\
\text { services. } \\
\text { Otherwise, the } \\
\text { ratio of } \\
\text { caregivers to } \\
\text { dementia is } \\
\text { not less than } \\
1: 4 \text {. }\end{array}$ & $\begin{array}{l}\text { (1)Life care } \\
\text { (2)Safety } \\
\text { care } \\
\text { (3)Non- } \\
\text { therapeutic } \\
\text { care } \\
\text { (4)Function } \\
\text { maintenance }\end{array}$ \\
\hline
\end{tabular}




\begin{tabular}{|c|c|c|c|c|c|c|c|}
\hline City & $\begin{array}{l}\text { Facility style that could } \\
\text { open a D-SCU }\end{array}$ & $\begin{array}{l}\text { Area } \\
\text { standard }\end{array}$ & $\begin{array}{l}\text { Environment } \\
\text { standard }\end{array}$ & Bed standard & $\begin{array}{l}\text { Manager } \\
\text { standard }\end{array}$ & $\begin{array}{l}\text { Care } \\
\text { personnel } \\
\text { standard }\end{array}$ & $\begin{array}{l}\text { Service } \\
\text { items }\end{array}$ \\
\hline Shanghai & $\begin{array}{l}\text { (1)Aged care facilities } \\
\text { (2)Care facilities that } \\
\text { provide home care } \\
\text { services for the elderly }\end{array}$ & $\begin{array}{l}\text { (1)The } \\
\text { usable } \\
\text { area of } \\
\text { single } \\
\text { room } \\
\text { should } \\
\text { not be } \\
\text { less } \\
\text { than } \\
7 \mathrm{~m}^{2} \text {. } \\
\text { (2)The } \\
\text { usable } \\
\text { area of a } \\
\text { single } \\
\text { bed in a } \\
\text { multi- } \\
\text { person } \\
\text { room } \\
\text { should } \\
\text { not be } \\
\text { less } \\
\text { than } \\
5 \mathrm{~m}^{2} \text {. }\end{array}$ & $\begin{array}{l}\text { "Small unit" } \\
\text { mode, with } \\
\text { home-style } \\
\text { and } \\
\text { humanized } \\
\text { spatial } \\
\text { layout, } \\
\text { creating a } \\
\text { family-style } \\
\text { living } \\
\text { environment. }\end{array}$ & $\begin{array}{l}6-18 \text { beds } \\
\text { per unit, } 1 \text { or } \\
\text { more units } \\
\text { can be set. }\end{array}$ & $\begin{array}{l}1 \text { full-time or } \\
\text { part-time "care } \\
\text { planning } \\
\text { commissioner" } \\
\text { is required. }\end{array}$ & $\begin{array}{l}\text { The ratio of } \\
\text { nursing staff } \\
\text { to dementia is } \\
\text { not less than } \\
1: 3 \text {, and all } \\
\text { personnel are } \\
\text { professionally } \\
\text { trained. }\end{array}$ & $\begin{array}{l}\text { (1)Daily care } \\
\text { (2)Self-care } \\
\text { ability } \\
\text { training } \\
\text { (3)Moral } \\
\text { support } \\
\text { (4)Social } \\
\text { interaction } \\
\text { (5) Support } \\
\text { services to } \\
\text { families in } \\
\text { need in the } \\
\text { community }\end{array}$ \\
\hline
\end{tabular}

\section{Efficiency evaluation}

\section{Basic information of inputs and outputs}

Table 3 showed the basic information of the inputs and the outputs of the 25 facilities surveyed. The 25 facilities surveyed had an average building area of $20,883.35 \mathrm{~m}^{2}$, an average of 504.60 open beds, and an average of 77.76 caregivers. On average, each facility had 83.56 elderly resident with dementia, and the average satisfaction of the elderly with the facility was 4.16 points. 
Table 3

Basic information of inputs and outputs of the 25 DMUs (facilities surveyed)

\begin{tabular}{|c|c|c|c|c|c|c|}
\hline \multirow[t]{2}{*}{ DMU } & \multirow{2}{*}{$\begin{array}{l}\text { Is there a } \\
\text { D-SCU }\end{array}$} & \multicolumn{3}{|l|}{ Inputs } & \multicolumn{2}{|l|}{ Outputs } \\
\hline & & $\begin{array}{l}\text { Building } \\
\text { area }\left(\mathrm{m}^{2}\right)\end{array}$ & $\begin{array}{l}\text { Number of } \\
\text { open beds }\end{array}$ & $\begin{array}{l}\text { Number of } \\
\text { nursing staff }\end{array}$ & $\begin{array}{l}\text { Number of elderly resident } \\
\text { with dementia }\end{array}$ & $\begin{array}{l}\text { Satisfaction of the elderly } \\
\text { resident with dementia }\end{array}$ \\
\hline DMU1 & No & 79304 & 459 & 185 & 163 & 3.87 \\
\hline DMU2 & No & 3800 & 809 & 17 & 26 & 4.24 \\
\hline DMU3 & Yes & 3800 & 450 & 18 & 50 & 4.35 \\
\hline DMU4 & No & 11200 & 811 & 55 & 15 & 4.33 \\
\hline DMU5 & Yes & 10000 & 296 & 48 & 21 & 4.13 \\
\hline DMU6 & Yes & 34547 & 252 & 79 & 23 & 4.17 \\
\hline DMU7 & No & 24875 & 600 & 73 & 21 & 3.93 \\
\hline DMU8 & No & 1200 & 66 & 7 & 7 & 4.11 \\
\hline DMU9 & Yes & 40000 & 1041 & 600 & 786 & 3.97 \\
\hline DMU10 & Yes & 600 & 155 & 5 & 6 & 4.33 \\
\hline DMU11 & No & 25580 & 245 & 18 & 15 & 4 \\
\hline DMU12 & No & 16584 & 982 & 101 & 55 & 4.27 \\
\hline DMU13 & Yes & 21500 & 112 & 42 & 50 & 4.33 \\
\hline DMU14 & No & 38643 & 158 & 87 & 146 & 4.05 \\
\hline DMU15 & No & 56339 & 66 & 120 & 14 & 4.42 \\
\hline DMU16 & Yes & 6900 & 20 & 37 & 60 & 4.17 \\
\hline DMU17 & Yes & 57000 & 18 & 64 & 30 & 4.21 \\
\hline DMU18 & No & 10000 & 600 & 31 & 19 & 4.37 \\
\hline DMU19 & Yes & 21116 & 1000 & 75 & 63 & 4.42 \\
\hline DMU20 & Yes & 31000 & 315 & 130 & 124 & 4.86 \\
\hline DMU21 & Yes & 10828 & 2780 & 57 & 205 & 3.47 \\
\hline DMU22 & Yes & 600 & 620 & 12 & 16 & 3.77 \\
\hline DMU23 & No & 1000 & 350 & 19 & 17 & 4.04 \\
\hline DMU24 & Yes & 4500 & 290 & 31 & 65 & 4.11 \\
\hline DMU25 & No & 11167 & 120 & 33 & 92 & 4.04 \\
\hline Mean & & 20883.35 & 504.60 & 77.76 & 83.56 & 4.16 \\
\hline
\end{tabular}

\section{DEA results}

Among the 25 facilities, there were 10 effective facilities (with an efficiency value of 1), accounting for $40 \%$ of the total number of facilities. The minimum TE was 0.147 and the average was 0.65 . The minimum PTE was 0.813 and the average was 0.97 . The minimum SE was 0.166 , and the average was 0.66 (Table 4). 
Table 4

DEA results of the 25 DMUs (facilities surveyed)

\begin{tabular}{|c|c|c|c|}
\hline DMUs & TE & PTE & SE \\
\hline DMU1 & 0.375 & 0.813 & 0.46 \\
\hline DMU2 & 0.601 & 0.97 & 0.62 \\
\hline DMU3 & 1 & 1 & 1 \\
\hline DMU4 & 0.159 & 0.959 & 0.166 \\
\hline DMU5 & 0.263 & 0.919 & 0.287 \\
\hline DMU6 & 0.208 & 0.898 & 0.231 \\
\hline DMU7 & 0.147 & 0.851 & 0.173 \\
\hline DMU8 & 1 & 1 & 1 \\
\hline DMU9 & 1 & 1 & 1 \\
\hline DMU10 & 1 & 1 & 1 \\
\hline DMU11 & 0.463 & 0.912 & 0.507 \\
\hline DMU12 & 0.256 & 0.927 & 0.276 \\
\hline DMU13 & 0.605 & 0.999 & 0.605 \\
\hline DMU14 & 0.798 & 1 & 0.798 \\
\hline DMU15 & 0.325 & 1 & 0.325 \\
\hline DMU16 & 1 & 1 & 1 \\
\hline DMU17 & 1 & 1 & 1 \\
\hline DMU18 & 0.296 & 0.984 & 0.301 \\
\hline DMU19 & 0.306 & 0.955 & 0.321 \\
\hline DMU20 & 0.442 & 1 & 0.442 \\
\hline DMU21 & 1 & 1 & 1 \\
\hline DMU22 & 1 & 1 & 1 \\
\hline DMU23 & 0.96 & 0.978 & 0.982 \\
\hline DMU24 & 1 & 1 & 1 \\
\hline DMU25 & 1 & 1 & 1 \\
\hline Mean & 0.648 & 0.967 & 0.66 \\
\hline Median & 0.605 & 1 & 0.62 \\
\hline
\end{tabular}

\section{Comparison of the efficiency of facilities with and without D-SCU}

Among the 25 surveyed facilities, 12 facilities set up D-SCUs, of which 8 were effective facilities, accounting for $66.67 \% .13$ facilities did not set up D-SCUs, of which 2 were effective facilities, accounting for $15.38 \%$. Comparing the efficiency of facilities with and without D-SCU, the TE, PTE and SE of the care for the elderly with dementia were all statistically different $(P<0.05)$. The means (medians) of TE for facilities with and without D-SCU were 0.8013 (1) and 0.5068 (0.3750) separately (Table 5). 
Table 5

Comparison of the care efficiency of facilities with and without D-SCU for the elderly with dementia

\begin{tabular}{|lllll|}
\hline Facilities & Effective facilities & TE & PTE & SE \\
\cline { 2 - 4 } & $\mathrm{n}(\%)$ & mean (median) & mean (median) & mean (median)
\end{tabular}

\begin{tabular}{|lllll|}
\hline With D-SCUs $(\mathrm{n}=12)$ & $8(66.67 \%)$ & $0.8013(1)$ & $0.9894(1)$ & $0.8046(1)$ \\
\hline Without D-SCUs $(\mathrm{n}=13)$ & $2(15.38 \%)$ & $0.5068(0.3750)$ & $0.9455(0.9704)$ & $0.5261(0.4600)$ \\
\hline $\mathrm{z}$ & & -2.417 & -2.287 & -2.304 \\
\hline$P$ & 0.016 & 0.022 & 0.021 \\
\hline \multicolumn{2}{|l}{ Note: TE: technical efficiency, PTE: pure technical efficiency, SE: scale efficiency } & \\
\hline
\end{tabular}

\section{Discussion}

The results of this study indicated that the care efficiency for the elderly with dementia of facilities with D-SCUs was higher than those without D-SCUs. Most facilities with D-SCUs arrange the space according to the physical and mental characteristics of the elderly with dementia[22-24], which can not only improve the care safety and reduce the care risk effectively, but also can relieve the physical constraints of the elderly with dementia and increase the space for activities. Besides, the D-SCUs generally has dedicated care personnel being professionally trained[19,23], who can grasp the needs of each elderly with dementia in time, and the incidence of the psychobehavioral symptoms will be reduced Furthermore, most D-SCUs provide more service items for the elderly with dementia besides daily life care, such as social interaction items, non-drug treatment items, etc. These special items can not only enhance social integration, but more importantly, relieve disease progression. All these can improve the care efficiency and the satisfaction of the elderly with dementia. At present, very limited long term care facilities are willing to accept or have the ability to accept the elderly with dementia in China[6]. Among facilities that accept the elderly with dementia, most facilities still adopt the traditional mixed residential model[25, 26]. In view of the limited care resources in China and the poor care quality of the elderly with dementia, adopting isolated residential mode, that is, setting up a D-SCU can improve the care efficiency and the satisfaction of the elderly, the D-SCU mode can be further promoted in China.

According to the spatial layout and management mode of the D-SCUs, the D-SCUs in China were divided into four types in this study: independent, semi-independent, semi-dependent, and dependent, which were basically the same with other countries[27, 28]. There were certain differences among different styles of D-SCUs in terms of living space, activity space, service personnel, etc. The space scales of independent D-SCUs are free, but the cost can be high, and the human resources may not be effectively used. Semi-independent design of DSCUs can further improve the utilization efficiency of space and human resources except for free space design. The space is limited for semidependent design of D-SCUs, but other resources in the care facilities can provide strong support for the D-SCUs. For the dependent design of D-SCUs, the space is limited, but the cost is low, and the elderly with dementia can share public space with other elderly, which can improve their participation in activities[29]. Internationally, after decades of exploration, the overall design concept of D-SCUs tends to be small-scale and grouping. A group generally reside 6 to 14 elderly people with dementia, and no more than 20. Studies[30] suggested that personalized care could be taken effectively for elderly in different situations in this model, which was conducive to improving care efficiency and quality significantly, improving social participation of the elderly with dementia effectively, and reducing negative emotions and behavior problems. Therefore, in the development of D-SCUs, small-scale and grouping can be applied as the main model, diversified designs can be explored based on available space and target group, in order to meet different needs of different elderly with dementia.

Regarding standards for D-SCUs, certain cities of China have issued relevant standards and norms in city level, such as Shanghai, Chengdu, and Qingdao, put forward requirements in terms of environment, staffing and service. In some other cities, although relevant standards or norms have not yet been issued at the city level, the care facilities have begun exploring standards of D-SCUs to provide better services for the elderly with dementia. However, in general, most cities or care facilities in China have not yet realized the particularity of care for the elderly with dementia, and have not yet begun to explore the D-SCU care model. In addition, even certain cities or institutions set standards for D-SCUs, the standards are various and not detailed. Qingdao has not made clear regulations for environmental settings and service personnel for example. Studies and explorations from a higher level of D-SCUs are urgent for China to improve care efficiency and quality for the elderly with dementia. Internationally, as early as 2000 , attention has been paid to the standards for D-SCUs. Regulations have been made for environmental design, care personnel, and service items. Regarding the environment, on the basis of small-scale and home-based design, in care facilities of some developed countries, special design will also be conducted according to the characteristics of the elderly

Page $9 / 12$ 
with dementia, such as safety design, circular walking path, nostalgic design, lighting and sound design, etc. [31, 32]. With regard to the caregivers, certain countries propose that the caregivers should be professionals and the caregiver-to-resident ratios must meet the regulations. For example, some states in the United States stipulate that the ratio of caregivers to the elderly with dementia is $1: 6$ in the daytime, and 1:10 at night[33]. In Japan, the ratio of caregivers to the elderly with dementia is 1:3[34]. With respect to the service items, some countries follow the people-oriented concept and pay attention to training on ability of daily life, rehabilitation care, and care of mental behavior symptoms to delay the progress of the disease. In Japan[34], caregivers of D-SCUs encourage the elderly with dementia to do housework, cook, and toilet on their own. Besides, they also pay attention to the non-drug interventions, and perform interventions such as music therapy, nostalgia therapy, and behavior therapy for the elderly with dementia, which have achieved good effects.

\section{Conclusion}

In conclusion, care facilities are the main facilities to guarantee professional care services for the elderly with dementia, and the care model that sets up D-SCUs in these care facilities is efficient and specialized. Accordingly, specific strategies should be implemented to promote the D-SCU model in China. However, guiding documents regarding the establishment of D-SCUs are lacked in China. Guiding opinions in terms of environmental design, care personnel, and service items for D-SCUs must be put forward from a higher level to standardize the care model and improve the care quality for the elderly with dementia.

\section{Abbreviations}

D-SCU: dementia special care unit; DEA: data envelopment analysis; DMU: decision-making unit; TE: technical efficiency; PTE: pure technical efficiency; SE: scale efficiency.

\section{Declarations}

\section{Ethics approval and consent to participate}

All subjects gave their informed consent for inclusion before they participated in the study. The study was conducted in accordance with the Declaration of Helsinki, and the study was approved by the Research Ethics Committee in Ningbo College of Health Sciences, Ningbo, China.

\section{Consent for publication}

Not applicable.

\section{Availability of data and materials}

The datasets used and/or analysed during the current study are available from the corresponding author on reasonable request.

\section{Conflicts of Interest}

The authors declare that they have no competing interests.

\section{Funding information}

The study was supported by the National Natural Science Foundation of China (Project number: 71774092) and Zhejiang Natural Science Foundation (Project number: LQ20H260006). The funders had no role in study design, data collection and analysis, and manuscript preparation.

\section{Acknowledgments}

We gratefully acknowledge funding support from the National Natural Science Foundation of China and Zhejiang Natural Science Foundation. We also appreciate all study participants who have been involved and contributed to the data collection.

\section{Author contributions}

XD conceived the idea and prepared a draft review protocol. XD, TS, NS and RJ provided the data. XD and LZ were involved in the data analysis and write up of the manuscript. RJ revised it critically for important intellectual content. All authors read and approved the manuscript. 


\section{References}

1. Alzheimer's Disease International. World Alzheimer Report 2009; London, 2009.

2. Alzheimer's Disease International. World Alzheimer Report 2019; Alzheimer's Disease International: London, 2019.

3. World Health Organization. Dementia A public health priority, WHO Western Pacific Region Publication: 2012.

4. Alzheimer's Disease International. Alzheimer Report 2015; Alzheimer's Disease International: London, 2015, 2015.

5. Jia J, Wei C, Chen S, Li F, Tang Y, Qin W. et al. The cost of Alzheimer's disease in China and re-estimation of costs worldwide. Alzheimer's \& Dementia 2017, 14, (4), 1-9.

6. Jia L, Quan M, Fu Y, Zhao T, Jia J. Dementia in China: epidemiology, clinical management, and research advances. The Lancet Neurology 2019, 19, (1).

7. Chiao $\mathrm{CY}$, Wu HS, Hsiao CY. Caregiver burden for informal caregivers of patients with dementia: A systematic review. International Nursing Review 2015, 62, (3), 340-350.

8. Reimer MA, Slaughter S, Donaldson C, Currie G, Eliasziw M. Special care facility compared with traditional environments for dementia care: a longitudinal study of quality of life. Journal of the American Geriatrics Society 2004, 52, (7), 1085-1092.

9. Cadigan RO, Grabowski DC, Givens JL, Mitchell SL. The Quality of Advanced Dementia Care in the Nursing Home: The Role of Special Care Units. Medical Care 2012, 50, (10), 856-862.

10. Kok JS, Berg IJ, Scherder EJA. Special Care Units and Traditional Care in Dementia: Relationship with Behavior, Cognition, Functional Status and Quality of Life - A Review. Dementia \& Geriatric Cognitive Disorders Extra 2013, 3, (1), 360-375.

11. Noble H, Mitchell G. What is grounded theory? Evid Based Nurs 2016, 34-35.

12. Wu CS, Rong JR. Relocation experiences of the elderly to a long-term care facility in Taiwan: a qualitative study. Scandinavian Journal of Caring Sciences 2020, 20, (1), 280.

13. Ozcan YA, Wogen SE, Mau LW. Efficiency Evaluation of Skilled Nursing Facilities. Journal of Medical Systems 1998, 22, (4), 211-224.

14. Bjrkgren MA, Hkkinen U, Linna M. Measuring Efficiency of Long-Term Care Units in Finland. Health Care Management Science 2001, 4, (3), 193-200.

15. Min A, Park CG, Scott LD. An Examination of Nursing Care Quality Efficiency in U.S. Nursing Homes: Using Data Envelopment Analysis. Western Journal of Nursing Research 2016, 38, (10), 1387-1388.

16. Garavagli G, Lettieri E, Agasisti T, Lopez S. Efficiency and quality of care in nursing homes: an Italian case study. Health Care Management Science 2011, 14, (1), 22-35.

17. Delellis NO, Ozcan YA. Quality outcomes among efficient and inefficient nursing homes. Health Care Management Review 2013, 38, (2), 156-165.

18. Min A, Park CG, Scott LD. Evaluating Technical Efficiency of Nursing Care Using Data Envelopment Analysis and Multilevel Modeling. Western Jounal of Nursing Research 2016, 38, (11), 1489-1508.

19. Shimshak DG, Lenard ML, Klimberg RK. Incorporating Quality into Data Envelopment Analysis of Nursing Home Performance: A Case Study. Omega 2009, 37, (3), 672-685.

20. Ni Luasa S, Dineen D, Zieba M. Technical and scale efficiency in public and private Irish nursing homes - a bootstrap DEA approach. Health Care Management Science 2018, 21, (3), 326-347.

21. Laine J, Linna M, Häkkinen U, Noro A. Measuring the productive efficiency and clinical quality of institutional long-term care for the elderly. Health Economics 2005, 14, (3), 245-256.

22. Abbott KM, Pachucki MC. Associations between social network characteristics, cognitive function, and quality of life among residents in a dementia special care unit: A pilot study. Dementia (London) 2017, 16, (8), 1004-1019.

23. Park-Lee E, Sengupta M, Harris-Kojetin LD. Dementia special care units in residential care communities: United States, 2010. NCHS Data Brief 2013, (134), 1-8.

24. Campo M, Chaudhury H. Informal social interaction among residents with dementia in special care units: Exploring the role of the physical and social environments. Dementia 2012, 11, (3), 401-423.

25. Li J. A study on type system and spatial mode of dementia care facilities. New Architecture 2017, (1), 76-81.

26. Shufen K. Chinese version of TESS-NH scale and research on its preliminary application. Fujian Medical University, Fuzhou, 2014.

27. E F, I L. Living for the Elderly: A Design Manual Second and Revised Edition. Walter de Gruyter: Berlin, 2018.

28. Fleming R, Purandare N. Long-term care for people with dementia: environmental design guidelines. International Psychogeriatrics 2010, 22, (7), 1084-1096. 
29. Williamson T. Designing and Delivering Dementia Services. Working with Older People 2014, 18, (3), 161-162.

30. Xu J, Li J. Design concept of facilities for the elderly with dementia abroad. Architectural Knowledge 2016, 36, (9), 42-45.

31. Chaudhury H, Cooke H. Design matters in dementia care: The role of the physical environment in dementia care settings. Excellence in dementia care (2nd Edition). Open University Press: UK, 2014.

32. Garre-Olmo J, López-Pousa S, Turon-Estrada A, Juvinyà D, Ballester D, Vilalta-Franch J. Environmental determinants of quality of life in nursing home residents with severe dementia. Journal of the American Geriatrics Society 2012, 60, (7), 1230-1236.

33. Alzheimer's Association. Dementia care practice recommendations for assisted living residences and nursing homes; Alzheimer's Association: Chicago, 2005.

34. Li G. The Care Model of the Elderly with Dementia and the Institutional Care Revolution in Japan. Taiwan Social Welfare Journal 2004, (5), 119-172.

\section{Supplementary Files}

This is a list of supplementary files associated with this preprint. Click to download.

- Additionalfile1.docx

- Additionalfile2.docx

- Additionalfile3.docx

- STROBEchecklistcrosssectional.doc 